This is an author produced version of a paper published in Small-scale Forest Economics, Management and Policy. This paper has been peerreviewed and is proof-corrected, but does not include the journal pagination.

Citation for the published paper:

Ola Lindroos, Gun Lidestav and Tomas Nordfjell (2005) Swedish nonindustrial private forest owners: a survey of self-employment and equipment investments. Small-scale Forest Economics, Management and Policy. Volume: 4 Number: 4, pp 409-425.

http://www.springerlink.com/content/j87862234425121v/

NB: The Journal has since been renamed Small-scale Forestry.

Access to the published version may require journal subscription. Published with permission from: Springer.

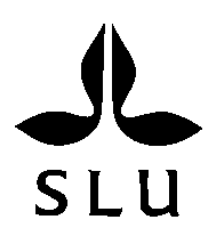

Epsilon Open Archive http://epsilon.slu.se 


\title{
Swedish Non-industrial Private Forest Owners - a Survey of Self-employment and Equipment Investments
}

\author{
Ola Lindroos, Gun Lidestav and Tomas Nordfjell \\ Department of Silviculture \\ Swedish University of Agricultural Sciences \\ SE-901 83 Umeå, Sweden \\ Published 2005 in Small-scale Forest Economics, Management and Policy 4(4), 409-426 \\ (now Small-scale Forestry)
}

\begin{abstract}
It has been estimated that Sweden's non-industrial private forest (NIPF) owners undertake a total of $12 \mathrm{M}$ hours of self-employed forest work per year. This paper reports an evaluation of self-employment in Swedish NIPF in terms of the people and equipment involved. NIPF owners' self-employment was determined by a nationwide questionnaire survey. Complete equipment sales statistics were compiled from interviews with manufacturers and importers. About $66 \%$ of NIPF owners are undertaking self-employed forestry work. Pre-commercial thinning was the activity undertaken most frequently by them, followed by planting, cutting and extraction. In comparison to other NIPF owners, self-employed NIPF owners tend to be younger, and are more likely to be male, single owners, resident on their holdings, farmers and members of forest owner associations. Sales of new equipment suitable for self-employed individuals amounted to $67 \mathrm{M}$ Euro, or 83,000 items. Based on sales numbers and the profile of self-employed NIPF owners, no major changes in the amount and nature of selfemployment are expected in the near future.
\end{abstract}

Keywords: Family forestry, private forestry, NIPF, forestry equipment, forestry machinery, sale statistics, questionnaire, owner characteristics

\section{Introduction}

Non-industrial private forests (NIPF) are dominant in Western Europe (Harrison et al. 2002). Sweden's 11.5 M hectare of NIPF consists of 239,000 holdings, owned by 354,000 individuals (National Board of Forestry 2004). Co-ownership of holdings is common. NIPF constitute $51 \%$ of the country's forest land and accounts for $58 \%$ of the wood increment (National Board of Forestry 2004). Hence, in Sweden, as in many other countries, NIPF owners have a major impact on the forest industry and the country's economic development. It is, therefore, highly relevant to analyse structural changes and behaviour in relation to NIPF owners. Studies on NIPF owners' objectives have been reviewed, for example, by Ingmarsson (2004).

Little attention has been paid to the forestry activities of NIPF owners, even though such work is common across northern Europe (see, for instance, Etelätalo 1989; Lidestav 1998; Pivoriunas and Lazdinis 2004). The term 'self-employed' is generally used to refer to forestry work conducted by NIPF owners and their family members on their own holdings (Hämäläinen and Kettunen 2001). Studies of self-employment have generally focused on measures of activity on holdings - e.g. amounts of timber supplied to industry - rather than the people involved, apparently because a prime concern has been to ensure that sufficient raw material supplies are maintained to meet industrial needs. The focus may, however, not reflect self-employment among NIPF owners in general.

Owning a forest holding implies a responsibility to manage that forest. Some activities are legally obligatory and some are voluntary. Generally, the amount of work involved is positively correlated with the size of the holding. In order to generate revenue, a threshold minimum work input is required. The work can be undertaken by the owners themselves, by hiring contractors or by a combination of the two. For logging in Sweden, the selfemployed work normally involves motor-manual and mechanised operations (i.e. the use of chainsaws and some kind of mechanised extraction equipment), whilst contractors' operations are fully mechanised (i.e. using harvesters and forwarders). Planting and pre-commercial thinning (PCT) are conducted in the same way, whether by selfemployed owners or by contractors. Planting is a manual operation and PCT is conducted motormanually.

Törnqvist (1992) found that, compared to NIPF owners who hire contractors for logging, Swedish 
NIPF owners who normally perform logging themselves were younger, were more likely to be farmers and more likely to be resident on their forest holdings. The same patterns have been found among Finnish NIPF owners (Hämäläinen and Kettunen 2001). However, both studies considered only a limited group of NIPF owners within their respective study areas.

The income of self-employed NIPF owner's from their forest holding includes both the compensation for their own labour (i.e. a salary) and the revenue. When hiring contractors, the revenue alone constitutes the income. Figure 1 illustrates these two modes of forest work and the major economic flows involved. How self-employed work affects the owner's overall finances depends on their work alternatives and the equipment used. If the owner has no better paid options, self-employment can be profitable even at low work compensation levels. A demand for high levels of compensation for the owner's labour will increase the efficiency requirement. According to Dahlin and Eriksson (1992), selfemployed logging is less cost-effective than hiring fully mechanised alternatives. Planting and PCT, in contrast, are more competitive (Dahlin and Eriksson 1992). NIPF owners in general are widely acknowledged to be interested in their holdings for both economic and other reasons (e.g. Kurtz and Lewis 1981; Bliss and Martin 1989; Kline et al. 2000). Similarly, Ager (1995) and Törnqvist (1995) argue that the self-employed NIPF owners' motives for undertaking forestry work includes aspects such as control of the holding, satisfaction derived from physical work and a tradition of self-employment, as well as its potential profitability.

With little or no compensation requirement, the owner's available time for forestry is the main factor affecting efficiency requirements. The less time that is available, the more efficient the equipment needs to be for a given amount of forest work (e.g. to thin a given area). Efficiency is, generally, positively correlated to the level of investment. Investment intervals depend on the equipment's lifespan. Factors other than efficiency also influence investments in equipment. The tax system, to some extent, promotes investment in equipment (Holmgren et al. 2005) and psycho-sociological reasons (e.g. advertisement and group pressure) are also probably involved in the decision process. Investments can serve as a forecast of future self-employed activities, because the purchase of new equipment indicates an intention to use it in subsequent years

In Sweden, self-employed forestry has a long tradition, with its roots in the self-sufficient agrarian society of previous centuries (Törnqvist 1995). Since 1975, the work performed by self-employed
NIPF owners accounted for half of the total number of working hours in Swedish forestry (National Board of Forestry 1994, 2004). However, the number of hours they worked, as well as the amount of work they undertook, decreased during the period from 1975 to 2002 (Table 1). Possible reasons for this decrease are a genuine reduction in activity and increased efficiency of the equipment used. Even though levels were lower in 2002 than in 1992, a considerable amount of work was still performed. During 1984, self-employed NIPF owners performed cutting on $50 \%$ of their holdings (Sennblad 1988). For extraction, planting and PCT the share of holdings involved were $40 \%, 20 \%$ and $42 \%$, respectively (Sennblad 1988). In the 1990s, self-employed forest work was undertaken on almost $88 \%$ of the holdings (Danielsson 1998).

During the period 1980-1992, mean annual sales of new tractor-drawn timber trailers amounted to 1,200 units (Trulson 1987; Herlitz 1993). Between 1987 and 1992, mean annual sales of new chainsaws and brushsaws totalled 46,100 and 18,400 units, respectively, (Trulson 1987; Herlitz 1993). In Sweden in 1992, the aggregated sales value of equipment for self-employment was estimated to be greater than the aggregated sales value of harvesters and forwarders (Herlitz 1993). A case study in northern Sweden found that $14 \%$ of the NIPF owners' turnover from cutting was reinvested in equipment (i.e. inventories) (Holmgren et al. 2005).

Little is known about a number of important aspects of self-employment. The model in Figure 1 illustrates the connection between NIPF owners, self-employed work and investment in equipment. This paper examines these issues by considering data from two surveys. Self-employed work was investigated by a postal survey of NIPF owners, while manufacturers and importers were interviewed about equipment sales. The extent of selfemployed work undertaken was not addressed. The studies' findings, their potential contribution to forecasting future self-employment trends and their implications for forestry extension are discussed.

\section{RESEARCH METHOD}

\section{Survey of Private Forest Owners}

A questionnaire was sent to a stratified sample of Sweden's NIPF owners. The survey design was developed in association with Statistics Sweden, who also handled the sampling of NIPF owners. The sampling frame was based on Skogsdataregistret (the Forestry database), which contains information on all NIPF owners and their forest holdings. All individuals aged between 18 and 80 years and own- 
ing at least 5.0 hectare of forest land were selected from the Forestry database. They were then stratified into three holding size classes (5-49, 50-399 and $>399$ hectare) and six ownership classes (single male owner; single female owner; multiple male owners only; multiple female owners only; male and female owners, male respondent chosen; male and female owners, female respondent chosen). Simple random sampling was conducted within each of these 18 strata. In total 2,500 NIPF owners were selected, with between 30 and 310 people per stratum. Sample sizes in relation to the population ranged from $0.5 \%$ to $48.6 \%$ in the strata. Prior to the study, the questionnaire was tested on 18 forest owners. Questionnaires were mailed in November 1997, and 1,461 usable replies had been received when the survey was closed in February 1998. The overall reply rate was $58 \%$, ranging from $41 \%$ to $73 \%$ in the different strata. Analysis of age and holding size indicated that there were no significant differences between respondents and nonrespondents. The questionnaire is described in Lidestav and Nordfjell (2002) and some of the survey's results relating to NIPF owners' activities and attitudes have previously been reported (Lidestav and Nordfjell 2002, 2005). In this paper, a more thorough analysis of self-employment is presented.

In the questionnaire, respondents were asked whether self-employed forest work was normally conducted by the respondent or by the respondent's family members and co-owners. Only the respondent's (i.e. the forest owners') self-employment was considered in this study. Activities chosen for this study were: cutting, extraction, planting and PCT. Self-employed work was not limited in level or amount. Hence, contractors could be hired for most of the forest work and the NIPF owner would still be considered self-employed. Furthermore, the focus was not on a particular period of time, since intervals between forestry work can be long. Based on this definition, all NIPF owners likely to own equipment were targeted. The selected descriptive owner characteristics include gender - importance reported by Lidestav (1998), age, participation in agricultural activities, holding size, membership of a forest owner association and residency - importance of all five variables reported by e.g. Törnqvist (1992).

Statistical inferences from the results of the different strata were made according to equation 1 for totals and equation 2 for ratio estimates (e.g. age). For all estimated population values, 95\% confidence intervals were calculated. Data were analysed for differences between the sub-populations 'selfemployed' and 'not self-employed' NIPF owners at the level of the characteristics. Analyses were con- ducted using bespoke Fortran programs, designed to account for the different inclusion probabilities of the strata. Comparisons were made using the Tstatistic (equation 3 ). In equation $3, \mathrm{c}$ is a vector of linear combinations of ratio estimators and $\mathrm{S}$ is the estimator of the covariance matrix of $\mathrm{c}$. In cases where there was no difference between subpopulations, the expected value of c, $E(\mathbf{c})$, equals zero. According to large sample theory, $\mathrm{T}$ has, approximately, a chi-square distribution if $E(\mathbf{c})=0$. In cases where there were only two classes for a characteristic (i.e. all characteristics except holding size and membership of a forest owner association), $\mathrm{T}$ is equivalent to the simple statistic $\mathrm{z}$ (equation 4 ). In equation $4, \hat{R}_{i}$ is the estimated ratio for the subpopulation $i$. The self-employed activities of cutting, extraction, planting and PCT were not independent and, therefore, were not tested for differences. The critical significance level was set at 5\%.

$$
\begin{aligned}
& \hat{Y}=\sum_{h=1}^{H} N_{h} \times \bar{y}_{h} \\
& \hat{R}=\frac{\hat{Y}}{\hat{X}}
\end{aligned}
$$

$\hat{Y}$ and $\hat{X}=$ estimators of population totals, $N_{h}=$ population size in the stratum $h, \bar{y}_{h}=$ mean in the stratum $h, H=$ number of strata, $R=$ estimated ratio for the population.

$$
\begin{aligned}
& T=\mathbf{c}^{\prime} \mathbf{S}^{-1} \mathbf{C} \\
& Z=\frac{\hat{R}_{1}-\hat{R}_{2}}{S E\left(\hat{R}_{1}-\hat{R}_{2}\right)}
\end{aligned}
$$

\section{Interviews with Manufacturers and Importers}

Full statistics pertaining to sales of equipment suitable for self-employed forestry in the Swedish market (excluding second-hand equipment) were gathered for the year 2002. Names of manufacturers and importers were identified throughout the data collection period from equipment catalogues, and advertisements in trade journals and on the internet. Sales representatives of the companies identified were interviewed by phone or in person, between February 2003 and September 2004. Equipment for cutting, extraction, PCT, mechanical site preparation and firewood procurement was included, separated into 17 categories (Table 2). Equipment that could not be classified as machinery or with a mean unit price of less than $€ 170$ was not included. The data collected included the number of new sales and the aggregated retail sales value for the Swedish market. Data collection was more detailed for three equipment categories. Chainsaws were categorised with 
respect to engine displacement. All-terrain vehicle (ATV) trailers were separated into hauling and skidding equipment. Only brushsaws with an engine displacement greater than $35 \mathrm{~cm}^{3}$ were included. A modified data set was collected for base machines for extraction (farm tractors, ATVs and snowmobiles); sales value was not collected and trade associations provided numbers of new sales. For snowmobiles, sales were recorded for the period July 2001 to June 2002. Technical specifications and prices for the equipment included, excluding base machines for extraction, can be found in Lindroos (2004).

Among the categories presented, only seven were considered to be exclusively used by self-employed NIPF owners and for forestry (Table 2). 'Other' use indicates that an investing NIPF owner might use the equipment for purposes other than forestry, while 'other' user groups indicate buyers other than NIPF owners. Estimating the proportions of the sales destined for forest work by self-employed NIPF owners was, therefore, difficult. Sales values were recorded in Swedish crowns (SEK), excluding value added tax, and converted to $€^{1}$.

In total, 101 companies were contacted, of which three importers refused to participate. Hence, the overall reply frequency was $97 \%$. All categories had a reply frequency of $100 \%$ except firewood processors $(95 \%)$, firewood splitters $(92 \%)$ and firewood cutters $(85 \%)$. One of the non-respondents was believed to hold a considerable market share for low price firewood splitters, while the other two were believed to hold moderate market shares. Sales statistics were considered to be a full survey of the entire population, and hence statistical analysis was not relevant. Estimates of the non-respondents' sales were not made since it was considered more valuable to have a precise minimum level of sales than an estimated total level.

\section{SURVEY FINDINGS}

\section{Self-employment among NIPF Owners}

In total, two thirds of the forest owners were selfemployed (Table 3), and this class included significantly higher $(p<.01)$ proportions of males, residents on the holding, farmers and members of forest owner associations than the NIPF owners who were not self-employed. The group of NIPF owners who did not conduct self-employed forestry contained a significantly higher $(p<.01)$ proportion of co-owners. The most significantly differentiating characteristic was gender, since the proportion of females was

\footnotetext{
${ }^{1} 1 €=9.16 \mathrm{SEK}$, in 2002 (Statistics Sweden 2003).
}

much higher among 'not self-employed' NIPF owners than in the total population. The mean age of the total population was $52.8 \pm 0.4$ years (mean $\pm 95 \%$ confidence interval (CI)) (not in table). Selfemployed NIPF owners were significantly $(p<.05)$ younger $(52.3 \pm 0.9$ years $)$ than those who were not self-employed $(54.0 \pm 1.3$ years $)$. No significant difference in age between the sexes was found. There was also no significant age difference between male self-employed and non self-employed NIPF owners, nor for the equivalent female comparison. Furthermore, there was no significant difference in the distribution of holding size between NIPF owners who were or were not self-employed.

The two most commonly undertaken activities were planting and PCT, which half of the total number of NIPF owners performed (Table 3). For all self-employed activities except planting, a smaller proportion of women participated than represented in the entire population of self-employed NIPF owners. In contrast, the proportion of single owners who performed planting themselves was lower than for any other activity considered. NIPF owners performing cutting and extraction were more likely to be resident on the holding and to be farmers than NIPF owners undertaking planting and PCT. The proportion of respondents who were members of a forest owner association was similar across the range of self-employed activities.

Undertaking all four activities was the most common combination, performed by $31 \pm 3 \%$ of the selfemployed NIPF owners (not in table). Only undertaking planting was the second most common category $(18 \pm 3 \%)$, followed by undertaking planting and PCT $(14 \pm 3 \%)$. The combination of cutting, planting and PCT was performed by $12 \pm 2 \%$ and only performing PCT by $8 \pm 2 \%$ of the respondents. Hence, $40 \pm 4 \%$ only performed planting, PCT or planting and PCT.

\section{Sales of New Equipment}

During 2002, the sales value of new equipment suitable for self-employed forestry was $€ 67.0 \mathrm{~m}$, and 83,901 units were sold (Table 4). Almost three times as many chainsaws were sold as the second most frequently sold type of equipment, brushsaws. Chainsaws also had the highest sales value, closely followed by grapple loader trailers. The types of equipment with a mean price per unit of more than $€ 4,000$ sold in the highest numbers were grapple loader trailers, followed by firewood processors. Firewood splitters and firewood processors were supplied by the highest number of manufacturers and importers, followed by grapple loader trailers. Firewood splitters were also available in the greatest range of models, followed by grapple loader trailers. 
In terms of the mean number of models offered per company, chainsaws with an engine displacement over $40 \mathrm{~cm}^{3}$ were the most diverse (8.2), followed by grapple loader trailers (4.6) and brushsaws (4.5).

The numbers of farm tractors, ATVs and snowmobiles sold amounted to 3,776, 3,211 and 8,265 units, respectively (Figure 3 ). The highest number of extraction units sold, in relation to base machines, was found in the category of ATVs. The ratio between the numbers of ATV-trailers and ATVs sold was less than 1:2. Of the ATV trailers sold, 94\% were designed for hauling (not in table). Among the forestry accessories for farm tractors, grapple loader trailers accounted for the highest numbers of units sold, with a ratio to farm tractors sold of slightly higher than 1:2. The ratio between numbers of snowmobile sleighs and snowmobiles sold was 1:20. During 2001 the proportion of snowmobiles capable of forest work (as a proportion of all snowmobiles) sold was 21\% (Snöfo 2002), and the proportion in 2002 was presumed to be the same. Corresponding information for farm tractors and ATVs was not available, but at least half of the machines sold were believed to be capable of forest work.

\section{Trends in Equipment Sales}

In 2002 , the sales value of seven comparable categories was 88\% of that in 1992 (Herlitz 1993) (Figure $2 \mathrm{~A}$ ), based on the monetary value in 2002 (Statistics Sweden 2003). Given the possible differences in survey coverage, as well as in NIPF owners' market share, it is difficult to say if there was a change related to self-employment.

For some equipment categories differences in sales can, however, be noted. More ATV trailers and grapple loader trailers were sold in 2002 than in 1992 (Figure 3B,C), while sales of snowmobile sleighs, wire cranes, small forwarders and miniforwarder decreased (Figure 3B-D). However, sales values for the two latter categories increased, indicating that the mean unit price had increased (Figure 2B).

There were notable changes in chainsaw and brushsaw sales between 1992 and 2002: their sales value decreased but the number of units sold remained the same, indicating that the mean unit price decreased (Figure 2B). Although consumption of firewood has been stable since 1990 (National Board of Forestry 2004), new sales of firewood splitters were eight times higher in 2002 than in 1986 (Trulson 1987) (Figure 3A).

\section{DISCUSSION}

The characteristics of self-employed NIPF owners found in this study were similar to those reported by Törnqvist (1992) and Hämäläinen and Kettunen (2001). Lower levels of self-employed NIPF owners were, however, found compared to previous studies with an equivalent definition of self-employment. Danielsson (1998), who targeted only the main responsible NIPF owner per holding, found a higher self-employment ratio (88\%). Responsibility for a forest holding was voluntarily allocated by coowners, and self-employed work probably scored highly in the selection process. Thus, the higher level of self-employment among Danielsson's respondents is not surprising. Törnqvist (1992) found a higher proportion $(64 \%)$ of self-employment associated with cutting activities than was found in the current study. His sample frame was NIPF owners participating in a forestry extension campaign, which might explain the difference.

The current study's definition of self-employment was not concerned with when the work was done, or how extensive it was, in an attempt to survey all NIPF owners likely to own forest equipment. In addition, this definition would be useful for injury prevention programs, since the risks associated with small amounts of work and tasks that are infrequently tackled can be high. However, the definition was more restricted than in other studies (cf. Hämäläinen and Kettunen 2001, National Board of Forestry 2004) since it excluded family members, who were also likely to own and use forest equipment. Estimates from the current study, however not completely covered by the sampling method, suggest that the inclusion of involved family members would add at least $30,000(14 \%)$ to the recorded number of 215,000 self-employed individuals.

The equipment sales presented here were probably not attributable solely to NIPF owners. However, there were many omissions from the list of investments (e.g. equipment categories, forestry's share of base machines, the second hand market and spare parts). In Sweden in 2002, turnover from cuttings was $€ 2,331 \mathrm{~m}$ (National Board of Forestry 2004). Assuming that the value is proportionally the same as the amount of cutting, $€ 1,333 \mathrm{~m}$ was generated by NIPF owners. In this context, the equipment sales presented in this study corresponded to $5 \%$ of all NIPF owners' turnover. In a case study based on taxation data, Holmgren, et al. (2005) found that $14 \%$ of the turnover from cuttings was invested in inventories (i.e. not only equipment). In terms of equipment purchases per hectare, inventory invest- 
ment amounted to $€ 7.3 /$ ha $\mathrm{NIPF}^{2}$ (Holmgren, et al. 2005). Equipment sales reported in the current study corresponded to $€ 5.8$ /ha NIPF. Despite discrepancies between the two studies, investment levels tally rather well.

Swedish equipment purchases per hectare for NIPF differed greatly from those recorded for neighbouring countries. In Finland in 2002, new chainsaws, brushsaws, grapple loader trailers and mini-forwarders with a total value of $€ 2.9 /$ ha NIPF were sold (Metla 2004; Sinisalo 2004). The corresponding sum for Sweden was €5.1/ha NIPF. Firewood equipment sales were also higher in Sweden than in Finland ( $€ 1.2$ and $€ 0.4$ per hectare NIPF, respectively) (Metla 2004; Sinisalo 2004). In Southwest Germany, mean annual investments in logging equipment amounted to $€ 29 /$ ha NIPF during 1986 to 2002 (Hartebrodt 2004). Possible explanations for these variations in investment values could probably be found in the differences in ecological conditions, forestry methods and owner structures. Germany differs greatly from Sweden in relation to these variables. Finland, in contrast, is more similar to Sweden and investment variations are believed to be a result of the smaller mean holding size in Finland (Metla 2004, National Board of Forestry 2004) and differences in tax systems (Stoeckmann 2001).

Investment in new equipment can be interpreted as an intention to use it in subsequent years. Cutting, PCT and planting can be performed with relatively inexpensive, hand-held equipment. Extraction, in contrast, needs specialised, often rather expensive equipment. Hence, equipment sales strongly imply a continuation of self-employed extraction. In the 1980 s, farm tractors with forestry accessories were the most common type of extraction equipment (Sennblad 1988). Accordingly, in the current study the proportion of farmers, and NIPF owners resident on the holding, was found to be highest among those performing extraction. Since the 1980s sales of farm tractors have decreased (Figure 3C), but sales of grapple loader trailers have been relatively stable, indicating that the use of farm tractors in forestry has not decreased.

Chainsaws and brushsaws differ from extraction equipment in terms of their lifespan, as well as their size and price. If the numbers of units sold of a certain type of equipment and the numbers of potential investors remain approximately constant, there should be at least a rough inverse correlation between the number of investors and the equipment's life span, as illustrated by the correlation between sales numbers and the numbers of self-employed NIPF owners. Sales of chainsaws with engine dis-

\footnotetext{
${ }^{2}$ Value adjusted to the monetary value in 2002 (Statistics Sweden 2003).
}

placement over $40 \mathrm{~cm}^{3}$ corresponded to $22 \%$ of the NIPF owners who performed cutting themselves. The equivalent numbers for brushsaws and extraction equipment were $11 \%$ and $5 \%$, respectively. Transformed into years, these numbers indicate that the lifespans of these types of equipment are 5, 9 and 20 years, respectively. Sales of equipment with long lifespans are more likely to give accurate longterm predictions of self-employment. When combining information on lifespan and equipment specialisation, predictions about self-employed activities can be more precise. For example, sales of grapple loader trailers can be used to give more accurate and longer-term predictions of self-employed extraction than sales data on chainsaws can provide about future cutting activities.

Based on the sales statistics, there were notable changes in the equipment used for extraction between 1992 and 2002. Numbers sold of both grapple loader trailers and ATV trailers increased, as did the number of manufacturers and importers, and the range of models they offered. In contrast, snow mobile sleighs, wire cranes, small forwarders and miniforwarder sales decreased. The mean price of units of the latter two categories also declined. In combination, these findings suggest that three changes are underway in the self-employed NIPF owners' use of extraction equipment: (1) grapple loaders are replacing the wire cranes as loaders of tractor timber trailers; (2) ATV timber trailers are replacing snowmobiles and mini-forwarders; and (3) small forwarders are being more commonly used by contractors.

The number of forest owners, and the proportion of holdings with self-employed activity, increased between 1975 and 1997 (Lidestav and Nordfjell 2005). Furthermore, the aggregated number of working hours, as well as the work performed, decreased between 1992 and 2002 (National Board of Forestry 1994, 2004). This study, however, reveals that sales of equipment were relatively stable. Improvement in equipment efficiency was not likely to be the major cause of such a large decrease in work time during the period, especially since also performed work decreased considerably. It is more likely that the manner of self-employment has changed. The self-employed NIPF owner uses the same type of equipment as previously, but apparently less work hours per year are performed on average. Thus, owners are generally exposed for short periods of time to the health and safety risks involved in forest work, and higher numbers of people with limited forest work experience are undertaking some of the work. In forestry, which involves relatively dangerous activities, short periods of seldomperformed work may be associated with high levels of risk. 
The sales study aimed to maximise coverage. It is not possible to determine whether this was achieved, but extended search of companies together with the high response rate suggests success. Those companies that were overlooked probably accounted for a small market share. Sales statistics were provided by the companies. Reliability was difficult to verify since sales data were not official and, in addition, could be considered sensitive material. In spite of its shortcomings, the method was believed to be efficient and allowed comparison with previous studies.

\section{CONCLUDING COMMENTS}

Sales statistics, generally, indicate that levels of self-employment among NIPF owners will continue to be high. No indications of a decrease in either extraction or cutting were seen in the short term. These two activities are, however, more closely correlated to the number of farmers and residents than planting and PCT, and thus are likely to be reduced by urbanisation in the long term. Levels of planting and PCT activity, in contrast, might increase as a result of urbanisation and ongoing structural changes in ownership. Undertaking just silvicultural work was found to be common in the current study and planting and PCT are likely to appeal even more to new generations of self-employed NIPF owners.

For the forest extension services, with responsibility for geographical areas, the increased amount of non-residency on forest holdings already presents problems when attempting to contact NIPF owners. Together with indications that self-employment will not decrease, but will involve higher numbers of less experienced workers, this presents new challenges in the future, both in terms of maintaining appropriate forest management and in preventing personal injuries.

This study found a high proportion of selfemployed NIPF owners, investing large amounts of money in equipment. This confirms that selfemployment is important for Swedish NIPF owners and will continue to be so in the years to come. To better understand and predict the nature and extent of self-employment in forestry, and the high levels of investment in money and time involved, further research is needed. Future studies should target both self-employed and other NIPF owners and would benefit from combining quantitative and qualitative methods.

\section{ACKNOWLEDGMENTS}

This study was conducted as part of the FORprogramme, which aims at improving NIPF owners' working conditions, and was financed by the Faculty of Forest Sciences at the Swedish University of Agricultural Sciences. We thank Dr Christoph Hartebrodt and an anonymous reviewer for valuable comments on the manuscript. We also thank senior lecturer Sören Holm for invaluable statistical advice and Sees Editing Ltd for revising the English.

\section{REFERENCES}

Ager, B. (1995), Om självverksamhet, rationalitet och teknikval i småskogsbruket, (Self-employment, efficiency and choice of technology in non-industrial private forestry), Research Notes No. 282, Department of Operational Effeciency, Swedish University of Agricultural Sciences, Garpenberg, 146 pp. [In Swedish with English summary].

Bliss, J. C. and Martin, A. J. (1989), 'Identifying Nipf management motivations with qualitative methods', Forest Science, 35(2): pp. 601-622.

Dahlin, B. and Eriksson, L. (1992), Better Profitability in Private Forestry - New Approaches, Report No 21, Department of Forest-Industry-Market Studies, Swedish University of Agricultural Sciences, Uppsala, 84 pp. [In Swedish with English summary].

Danielsson, B. (1998), Skogliga aktörer och den nya skogspolitiken, (Forest actors and the new forest policy), Meddelande 2-1998, National Board of Forestry, Jönköping, Sweden, 87 pp. [In Swedish with English summary].

Etelätalo, E. (1989), 'Self-employment and methods used in silvicultural jobs in privately owned woodlots in Finland', Työtehoseuran jukaisuja 309, Work Efficiency Institute, Helsinki, 162 pp. [In Finnish with English summary].

Harrison, S.R., Herbohn, J.L. and Niskanen, J. (2002), 'Non-industrial, smallholder, small-scale and family forestry: What's in a name?', Small-Scale Forest Economics, Management and Policy, 1(1): pp. 1-11.

Hartebrodt, C. (2004), 'The impact of storm damage on small-scale forest enterprises in the south west of Germany', Small-Scale Forest Economics, Management and Policy, 3(2): pp. 203-222.

Herlitz, A. (1993), The Sales of Small-scale Forestry Equipment 1980-92, Research Notes No. 242, Department of Operational Efficiency, Swedish University of Agricultural Sciences, Garpenberg, 37 pp. [In Swedish with English summary]

Holmgren, L., Lidestav, G. and Nyquist, S. (2005), 'Taxation and investment implications of non-industrial private forestry within a Boreal Swedish municipality', Small-Scale Forest Economics, Management and Policy, 4(1): pp. 35-51.

Hämäläinen, A. and Kettunen, A. (2001), Selfemployment and Working Methods in Delivery Sales of Timber by Finnish Non-industrial Private Forest 
Owners, TTS Institute's Publications 378, TTS Institute, Helsinki, $60 \mathrm{pp}$.

Ingmarsson, F. (2004), 'Small-scale forestry in Sweden: Owners' objectives, silvicultural practices and management plans', Acta Universitatis Agriculturae Suecia Silvestria 318, Swedish University of Agricultural Sciences, Uppsala, 112 pp.

Kline, J.D., Alig, R.J. and Johnson, R.L. (2000), 'Fostering the production of nontimber services among forest owners with heterogeneous objectives', Forest Science, (462), pp. 302-311.

Kurtz, W.B. and Lewis, B.J. (1981), 'Decision-making framework for nonindustrial private forest owners: An application in the Missouri Ozarks', Journal of Forestry, 79:5, pp. 285-288

Lidestav, G. (1998), 'Women as non-industrial private forest landowners in Sweden', Scandinavian Journal of Forest Research, 13(1), pp. 66-73.

Lidestav, G. and Nordfjell, T. (2002), Med skogsägaren i fokus, (With the Forest Owner in Focus), LRF Skogsägarna, 56 pp. [In Swedish].

Lidestav, G. and Nordfjell, T. (2005), 'Swedish nonindustrial private forestry in transformation', in the proceedings from Forest Operation Improvements in Farm Forest, 9-14 Sept 2003, Logarska Dolina, Slovenien, FAO, Rome, pp. 129-135.

Lindroos, O. (2004), Sammanställning av småskalig skogsutrusting, (Compilation of Small-scale Forestry Equipment), Department of Silviculture, Swedish University of Agricultural Sciences, Umeå, 197 pp., http://wwwssko.slu.se/ diwa/FOR.htm, 2005-03-07. [In Swedish].

Metla (2004), Finnish Statistical Yearbook of Forestry, Finnish Forest Research Institute (Metla), Helsinki, 416 pp. [In Finnish].

National Board of Forestry (1994), Statistical Yearbook of Forestry 1994, Jönköping, Sweden, 349 pp. [In Swedish].

National Board of Forestry (2004), Swedish Statistical Yearbook of Forestry 2004, Jönköping, Sweden, 328 pp. [In Swedish].

Pivoriunas, A. and Lazdinis, M. (2004) 'Needs of private forest owners in the context of changing political system: Lithuania as a case study', Small-Scale Forest Economics, Management and Policy, 3(2): pp. 191202.

Sennblad, G. (1988), Survey of Logging and Silviculture in Non-industrial Private Forestry in Sweden 1984. Part 1. Logging and Silviculture and Who Performed the Forest Work, Report No 175, Department of Operational Efficiency, Swedish University of Agricultural Sciences, Garpenberg, 210 pp. [In Swedish with English summary].
Sinisalo, R. (2004), Maatalous- ja metsäkoneiden myynti vounna 2000-2002 (Sales of Agricultural and Forestry Machinery 2000-2002), Verkkojulkaisu päivitetty MTT Agrifood Research Finland, Olkkala, 8 pp, [In Finnish] http://www.mtt.fi/tutkimus/teknologia/TILASTOKOKO. pdf, accessed 6 September 2005.

Snöfo (2002), Fakta om snöskoter (Facts about Snowmobiles), Sweden's Snowmobile Manufacturers Association (Snöfo), Stockholm, 24 pp. [In Swedish].

Statistics Sweden (2003), Statistical Yearbook of Sweden 2004, Stockholm, 725 pp. [In Swedish].

Stoeckmann, K. (2001), Taxation of Forest Ownership - a Comparative Study between Sweden and Finland, Examensarbete 2001:10, School for Forest Engineers, Swedish University of Agricultural Sciences, Skinnskatteberg, 49 pp. [In Swedish with English abstract].

Trulson, B. (1987), The sales of small-scale forestry equipment 1980-1986, Research Notes No. 109, Department of Operational Efficiency, Swedish University of Agricultural Sciences, Garpenberg, 28 pp. [In Swedish]

Törnqvist, T. (1992), The Forest Owners and Their Connection with Their Environment: a Study of Forestry Network and Working Relations between Private Nonindustrial Forest Owners and Actors inTtheir Environment, Report No 22, Department of ForestIndustry-Market Studies, Swedish University of Agricultural Sciences, Uppsala, 86 pp. [In Swedish with English summary].

Törnqvist, T. (1995), Inheritors of the Woodlands. A sociological Study of Private, Non-Industrial Forest Ownership, Report No 41, Department of ForestIndustry-Market Studies, Swedish University of Agricultural Sciences, Uppsala, 460 pp. [In Swedish].

If you don't want to change the lines in a table but want to use the style Table content, highlight the table before selecting the style from the toolbar.

If you want to put wide images and tables into the text section, you need to insert two section breaks and between them change the number of columns to one (Word 2003: menu Format $>$ Columns, Word 2007: tab Page layout > Columns).

\section{Delete the help text}

When you delete this help text, be careful not to delete the section break below. You can show the invisible formatting marks by clicking the icon with the symbol $\uparrow$ (the paragraph mark). 


\section{Tables and Figures.}

Table 1. Forest work performed by self-employed Swedish NIPF owners

\begin{tabular}{llllll}
\hline Year & $\begin{array}{l}\text { Working hours } \\
\left(10^{6} \mathrm{~h}\right)\end{array}$ & $\begin{array}{l}\text { Cutting } \\
\left(10^{6} \mathrm{~m}^{3}\right)\end{array}$ & $\begin{array}{l}\text { Extraction } \\
\left(10^{6} \mathrm{~m}^{3}\right)\end{array}$ & $\begin{array}{l}\text { Planting } \\
\left(10^{3} \mathrm{ha}\right)\end{array}$ & $\begin{array}{l}\text { Pre-commercial thinning } \\
\left(10^{3} \mathrm{ha}\right)\end{array}$ \\
\hline 2002 & 12.1 & 6.1 & 6.7 & 31.5 & 114.5 \\
1992 & 23.8 & 9.3 & 8.5 & 51.3 & 120.1 \\
1984 & 25.7 & - & - & - & - \\
1975 & 26.3 & - & - & - & - \\
\hline
\end{tabular}

- missing values.

Source: National Board of Forestry 1994, 2004.

Table 2. Equipment categories suitable for self-employed forestry

\begin{tabular}{|c|c|c|c|c|c|c|}
\hline \multirow[b]{2}{*}{ Activity } & \multirow[b]{2}{*}{ Equipment category $^{1}$} & \multicolumn{2}{|l|}{ Use } & \multicolumn{3}{|c|}{ User } \\
\hline & & Forestry & Other & $\begin{array}{l}\text { Self- } \\
\text { employed } \\
\text { NIPF owners }\end{array}$ & Contractors & Others \\
\hline \multirow[t]{3}{*}{ Cutting } & Chainsaws & $\mathrm{X}$ & $x$ & $\mathrm{X}$ & & $x$ \\
\hline & Tree jacks & $\mathrm{X}$ & & $\mathrm{X}$ & $x$ & \\
\hline & $\begin{array}{l}\text { Tractor-mounted } \\
\text { processors }\end{array}$ & $\mathrm{X}$ & & $\mathrm{X}$ & & \\
\hline \multirow[t]{9}{*}{ Extraction } & Farm tractors & $x$ & $\mathrm{X}$ & $x$ & & $\mathrm{X}$ \\
\hline & Grapple loader trailers & $\mathrm{X}$ & & $\mathrm{X}$ & & \\
\hline & Wire cranes & $\mathrm{X}$ & & $\mathrm{X}$ & & \\
\hline & Small forwarders & $\mathrm{X}$ & & $\mathrm{X}$ & $x$ & \\
\hline & Mini-forwarders & $\mathrm{X}$ & $x$ & $\mathrm{X}$ & & \\
\hline & $\begin{array}{l}\text { All-terrain vehicles } \\
\text { (ATVs) }\end{array}$ & $x$ & $\mathrm{X}$ & $x$ & & $X$ \\
\hline & ATV-trailers & $\mathrm{X}$ & & $\mathrm{X}$ & & \\
\hline & Snowmobiles & $x$ & $\mathrm{X}$ & $x$ & & $X$ \\
\hline & Snowmobile sleighs & $\mathrm{X}$ & & $\mathrm{X}$ & & \\
\hline $\begin{array}{l}\text { Pre-commercial } \\
\text { thinning }\end{array}$ & Brushsaws & $\mathrm{X}$ & & $\mathrm{X}$ & $x$ & \\
\hline Site preparation & $\begin{array}{l}\text { Tractor-mounted } \\
\text { scarifiers }\end{array}$ & $\mathrm{X}$ & & $\mathrm{X}$ & & \\
\hline \multirow[t]{3}{*}{$\begin{array}{l}\text { Fire wood procure- } \\
\text { ment }\end{array}$} & Firewood cutter & $\mathrm{X}$ & & $\mathrm{X}$ & & $x$ \\
\hline & Firewood splitter & $\mathrm{X}$ & & $\mathrm{X}$ & & $x$ \\
\hline & Firewood processors & $\mathrm{X}$ & & $\mathrm{X}$ & & $x$ \\
\hline
\end{tabular}

Note: Main use or user is marked with a capital X; minor use or user is marked with a lower case $x$.

${ }^{1}$ Tree jacks are mechanical, pole-like devices which propel the tree in the intended direction when felling motor-manually. Tractor-mounted processors de-branch and cross-cut felled trees. Grapple loader trailers are tractor-drawn timber trailers with hydraulic grapple loaders. Small forwarders are equipped with a small hydraulic grapple loader and have a mass of 1 to 2 tonnes, excluding payload. Mini-forwarders are track- or wheel-driven all-terrain vehicles with a mass lower than one tonne, manoeuvred by an operator on foot. Depending on whether a trailer is fitted, timber is hauled or skidded. Firewood cutters crosscut logs and firewood splitters split the crosscut wood. Firewood processors perform both crosscutting and splitting. 
Table 3. Characteristics of NIPF owner groups defined as self-employed in forestry work (value or percentage $\pm 95 \%$ confidence interval (CI))

\begin{tabular}{|c|c|c|c|c|c|c|c|c|c|c|c|c|}
\hline \multirow[b]{3}{*}{ NIPF owner group } & \multirow{3}{*}{$\begin{array}{l}\text { Number of } \\
\text { forest } \\
\text { owners* }\end{array}$} & \multirow{2}{*}{\multicolumn{2}{|c|}{ Gender (\%) }} & \multicolumn{2}{|c|}{ Ownership (\%) } & \multicolumn{2}{|c|}{ Residency (\%) } & \multirow{2}{*}{\multicolumn{2}{|c|}{$\begin{array}{l}\text { Undertaking } \\
\text { agricultural activity } \\
(\%)\end{array}$}} & \multirow{2}{*}{\multicolumn{3}{|c|}{$\begin{array}{l}\text { Member of a forest } \\
\text { owner association (\%) }\end{array}$}} \\
\hline & & & & \multirow{2}{*}{$\begin{array}{l}\text { Single } \\
\text { owner }\end{array}$} & \multirow{2}{*}{$\begin{array}{l}\text { Co- } \\
\text { owner }\end{array}$} & \multirow{2}{*}{$\begin{array}{l}\text { On } \\
\text { holding }\end{array}$} & \multirow{2}{*}{$\begin{array}{l}\text { Outside } \\
\text { holding }\end{array}$} & & & & & \\
\hline & & Male & Female & & & & & Yes & No & Yes & No & Don't know \\
\hline Total population $(n=1,416)$ & 322,240 & 63 & 37 & 35 & 65 & $48 \pm 3$ & $50 \pm 3$ & $29 \pm 3$ & $70 \pm 3$ & $47 \pm 3$ & $48 \pm 3$ & $4 \pm 3$ \\
\hline Self-employed** $(n=912)$ & $215,117 \pm 8,050$ & $77 \pm 2^{\mathrm{a}}$ & $23 \pm 2^{\mathrm{a}}$ & $38 \pm 2^{\mathrm{a}}$ & $62 \pm 2^{\mathrm{a}}$ & $54 \pm 4^{\mathrm{a}}$ & $45 \pm 4^{\mathrm{a}}$ & $34 \pm 3^{\mathrm{a}}$ & $65 \pm 3^{\mathrm{a}}$ & $52 \pm 4^{\mathrm{a}}$ & $46 \pm 4^{\mathrm{a}}$ & $2 \pm 5^{\mathrm{a}}$ \\
\hline Not self-employed $(n=549)$ & $107,123 \pm 8,050$ & $34 \pm 4^{\mathrm{b}}$ & $66 \pm 4^{\mathrm{b}}$ & $28 \pm 3^{\mathrm{b}}$ & $72 \pm 3^{b}$ & $37 \pm 5^{\mathrm{b}}$ & $62 \pm 5^{b}$ & $19 \pm 4^{\mathrm{b}}$ & $80 \pm 4^{b}$ & $37 \pm 5^{\mathrm{b}}$ & $54 \pm 5^{\mathrm{b}}$ & $8 \pm 2^{\mathrm{b}}$ \\
\hline \multicolumn{13}{|l|}{ Self-employment activity } \\
\hline Cutting $(n=487)$ & $126,541 \pm 7,544$ & $97 \pm 1$ & $3 \pm 1$ & $46 \pm 3$ & $54 \pm 3$ & $60 \pm 5$ & $39 \pm 5$ & $41 \pm 5$ & $59 \pm 5$ & $52 \pm 5$ & $46 \pm 5$ & $2 \pm 1$ \\
\hline Extraction $(n=354)$ & $90,207 \pm 7,628$ & $97 \pm 2$ & $3 \pm 2$ & $47 \pm 4$ & $53 \pm 4$ & $65 \pm 5$ & $34 \pm 5$ & $46 \pm 6$ & $54 \pm 6$ & $55 \pm 6$ & $43 \pm 6$ & $2 \pm 1$ \\
\hline Planting $(n=734)$ & $170,421 \pm 9,079$ & $75 \pm 3$ & $25 \pm 3$ & $39 \pm 2$ & $61 \pm 2$ & $55 \pm 4$ & $44 \pm 4$ & $35 \pm 4$ & $64 \pm 4$ & $57 \pm 4$ & $42 \pm 4$ & $2 \pm 1$ \\
\hline $\begin{array}{l}\text { Pre-commercial thinning } \\
(n=656)\end{array}$ & $158,481 \pm 7,820$ & $90 \pm 2$ & $10 \pm 2$ & $44 \pm 2$ & $56 \pm 2$ & $55 \pm 4$ & $44 \pm 4$ & $37 \pm 4$ & $63 \pm 4$ & $52 \pm 4$ & $46 \pm 4$ & $2 \pm 1$ \\
\hline
\end{tabular}

* Aged between 18 and 85 years and forest holding $\geq 5$ ha. ${ }^{* *}$ Normally self-employed, not limited by time or extent. ${ }^{\text {a, b }}$ Different letters within a column indicate significantly different values $(p<.05)$.

Note: Sample frame values or proportions are presented without CI. Tests for significant differences between self-employment activities were not conducted, since NIPF owners could perform several self-employed activities and hence be included in several groups (e.g. both cutting and extraction). Deviations from totals of $100 \%$ are due to failures to reply or rounding errors. 
Table 4. New sales of equipment: categories suitable for self-employed forestry in Sweden in 2002, value added tax excluded

\begin{tabular}{|c|c|c|c|c|c|}
\hline \multirow[b]{2}{*}{$\begin{array}{l}\text { Activity and } \\
\text { equipment category }\end{array}$} & \multirow[b]{2}{*}{$\begin{array}{l}\text { Number of manufac- } \\
\text { turers \& importers }\end{array}$} & \multirow[b]{2}{*}{$\begin{array}{l}\text { Number of } \\
\text { models }\end{array}$} & \multicolumn{3}{|l|}{ New sales } \\
\hline & & & $\begin{array}{l}\text { Number of } \\
\text { units }\end{array}$ & $\begin{array}{l}\text { Sales value } \\
\left(10^{6} €\right)\end{array}$ & $\begin{array}{l}\text { Average } \\
\text { price/unit } \\
\left(10^{3} €\right)\end{array}$ \\
\hline \multicolumn{6}{|l|}{ Cutting } \\
\hline Chainsaws, $<40 \mathrm{~cm}^{3}$ & - & - & 19,335 & 4.85 & 0.25 \\
\hline Chainsaws, $>40 \mathrm{~cm}^{3}$ & 6 & 49 & 28,390 & 12.43 & 0.44 \\
\hline Tree jacks & 6 & 10 & 760 & 0.25 & 0.33 \\
\hline Tractor-mounted processors & 4 & 8 & 152 & 3.34 & 21.97 \\
\hline \multicolumn{6}{|l|}{ Extraction } \\
\hline Grapple loader trailers & 18 & 82 & 1,611 & 16.30 & 10.12 \\
\hline Wire cranes & 2 & 2 & 130 & 0.17 & 1.31 \\
\hline Small forwarders & 5 & 6 & 58 & 1.82 & 31.38 \\
\hline Mini-forwarders & 4 & 5 & 125 & 0.89 & 7.12 \\
\hline ATV-trailers & 15 & 47 & 1,710 & 2.43 & 1.42 \\
\hline Snowmobile sleighs & 6 & 10 & 404 & 0.18 & 0.45 \\
\hline \multicolumn{6}{|l|}{ Pre-commercial thinning } \\
\hline Brushsaws, $>35 \mathrm{~cm}^{3}$ & 6 & 27 & 17,956 & 9.92 & 0.55 \\
\hline \multicolumn{6}{|l|}{ Site preparation } \\
\hline Tractor-mounted scarifiers & 5 & 12 & 59 & 0.24 & 4.07 \\
\hline \multicolumn{6}{|l|}{ Firewood procurement } \\
\hline Firewood cutter ${ }^{(\mathrm{i}}$ & 13 & 19 & 1,116 & 0.82 & 0.73 \\
\hline Firewood splitter $^{(\mathrm{i}}$ & 24 & 96 & 10,944 & 8.17 & 0.75 \\
\hline Firewood processors ${ }^{(\mathrm{ii}}$ & 21 & 37 & 1,151 & 5.19 & 4.51 \\
\hline Total & 101 & 398 & 83,901 & 67.00 & 0.80 \\
\hline
\end{tabular}

- = missing values $; i=$ two importers chose not to contribute new sales data; $i \mathrm{i}=$ one importer chose not to contribute new sales data; iii $=$ total number of individual companies. Some companies were active within several equipment categories. Note: $\mathrm{cm}^{3}$ refer to the engine displacement of the chain- and brushsaws. 


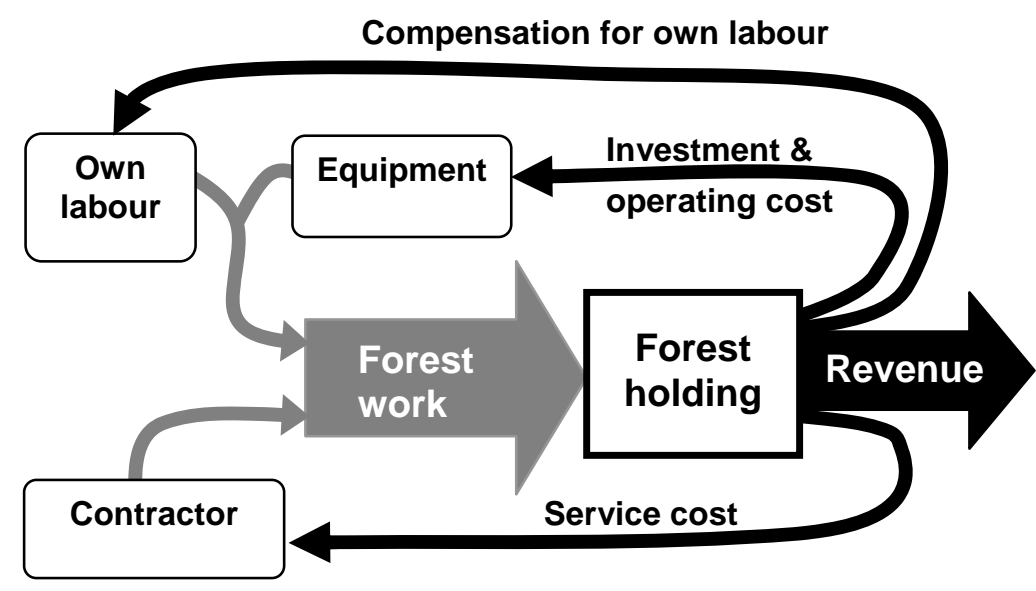

Figure 1. Possible ways for NIPF owners to carry out forest work and the major economic flows involved. Note: In the upper loop work is in the form of self-employment, while in the lower loop professional labour and equipment are hired. Both loops can be simultaneously operational on a forest holding.

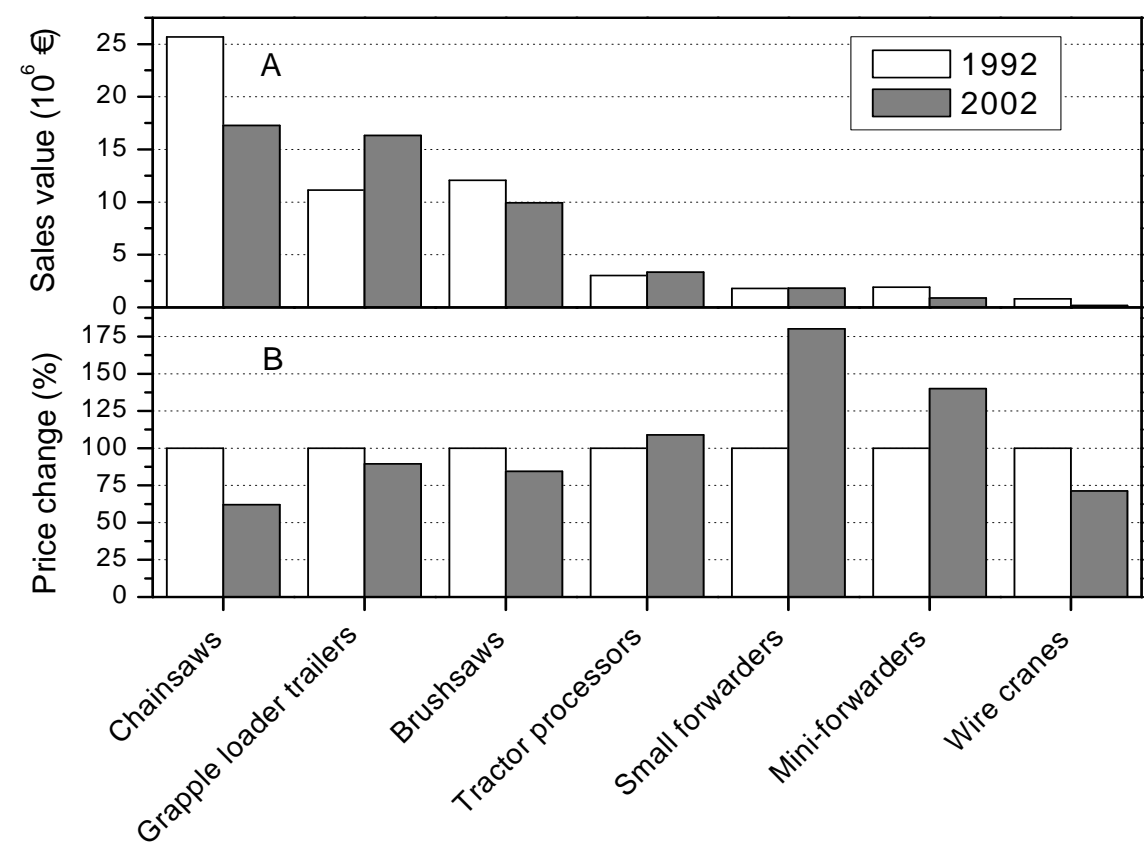

Figure 2. Swedish aggregated retail sales values in 1992 and 2002 (A) and proportional change in mean price per unit sold between these years (B) for seven types of equipment suitable for self-employed forestry.

Note: Values exclude value added tax and are adjusted to the monetary value in 2002 (Statistics Sweden 2003).

Source for sales in 1992: Herlitz (1993). 

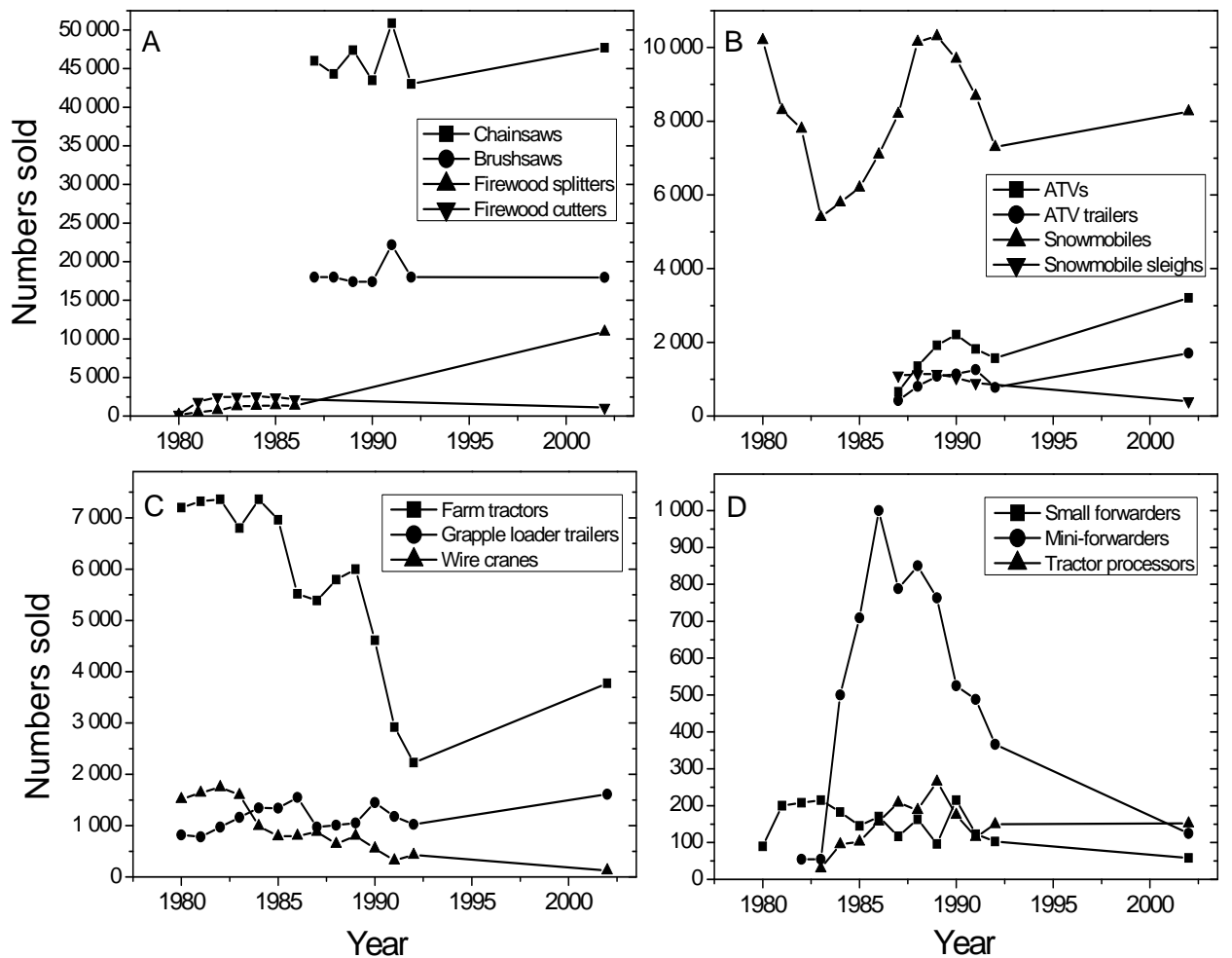

Figure 3. Annual Swedish sales of new equipment suitable for self-employed forestry in the period 1980 to 2002 Note: different scales on the y-axis.

Source: 1980-1986 Trulsson (1987), 1987-1992 Herlitz (1993). 